\title{
Cytokine action and oxidative stress response in differentiated neuroblastoma SH-SY5Y cells ${ }^{\star \star}$
}

\author{
Joanna Kania, Aleksandra Barańska and Amalia Guzdek ${ }^{\bowtie}$ \\ Department of Cell Biochemistry, Faculty of Biotechnology, Jagiellonian University, \\ Kraków, Poland
}

Received: 30 may, 2003; revised: 11 August, 2003; accepted: 10 September, 2003

Key words: cytokines, $\mathrm{NF} \kappa \mathrm{B}, \mathrm{MnSOD}$, neuroblastoma cells, PDTC

\begin{abstract}
In the retinoic acid-differentiated neuroblastoma SH-SY5Y cells, IL-1 induced binding activity of $\mathrm{NF} \kappa \mathrm{B}$ and up-regulated the expression and activity of MnSOD. The IL-1-elicited effects were partly reversed by IL-4 and IL-6. It is proposed that IL-4 and IL-6 may participate in the regulation of the imbalanced oxidant status induced by IL-1 in differentiated neuroblastoma cells. In the SH-SY5Y cell line, TNF $\alpha$ neither activated NF $\kappa$ B nor induced MnSOD expression and activity, but was capable of modulating the IL-1 effects. Pyrrolidine dithiocarbamate (PDTC), an inhibitor of NF $\kappa$ B activation, down-regulated the expression and activity of MnSOD, which may suggest that the regulation of MnSOD by $\mathrm{IL-1}$ in retinoic acid-differentiated neuroblastoma cells was mediated by the nuclear factor $\kappa \mathrm{B}$.
\end{abstract}

The oxidative stress-responsive nuclear factor $\kappa \mathrm{B}(\mathrm{NF} \kappa \mathrm{B})$ is the main regulator of immune-related functions (Pahl, 1999; Bowie \& O'Neil, 2000). By binding to specific sites in the promotor region, it regulates a number of genes associated with inflammation, lymphoid organ development, cell adhesion and apoptosis (Karin \& Lin, 2002). In several types of cells, activation of $\mathrm{NF} \kappa \mathrm{B}$ is central to the regulation of many genes by proinflammatory cytokines such as IL- $1 \beta$ or $\mathrm{TNF} \alpha$ which rapidly induce $\mathrm{NF} \kappa \mathrm{B}$ DNA-binding activity. The activation pathway utilizes the $\operatorname{IKK} \beta$ catalytic subunit, and is accomplished by $\mathrm{I} \kappa \mathrm{B}$ phosphorylation, followed by ubiquitin-dependent degradation (Israel,

\footnotetext{
* Presented at the XXX Winter School of Faculty of Biotechnology, Jagiellonian University, Kościelisko, Poland, 28th February-4th March, 2003.

${ }^{\circledR}$ To whom correspondence should be addressed: Amalia Guzdek, Department of Cell Biochemistry, Faculty of Biotechnology, Jagiellonian University, ul. Gronostajowa 7, 30-387 Kraków, Poland; tel.: (48 12) 252 6341; fax: (48 12) 252 6902; e-mail: Amag@mol.uj.edu.pl
}

Abbreviations: BCA, bicinchoninic acid; EMSA, electrophoretic mobility shift assay; FBS, fetal bovine serum; $\mathrm{NF} \kappa \mathrm{B}$, nuclear factor kappa $\mathrm{B}$; NBT, nitro blue tetrazolium; MnSOD, manganese superoxide dismutase; PDTC, pyrrolidine dithiocarbamate; RA, retinoic acid. 
2000). It has been well established that oxidative stress can trigger the production of cytokines which, in turn, induce the synthesis of proteins such as manganese superoxide dismutase (MnSOD) (Antras-Ferry et al., 1997; Rogers et al., 2001), which protects cells against the damage caused by reactive oxygen species. $\mathrm{Xu}$ et al. (1999) cloned human MnSOD gene, and found several NF $\kappa \mathrm{B}$ binding sites in the $3^{\prime}$ and $5^{\prime}$ flanking and the intronic regions. The authors suggested that the location of $\mathrm{NF} \kappa \mathrm{B}$ elements in the MnSOD gene is critical for the IL-1-elicited induction, but in cooperation with other transcription elements. In the present study we examined the effects of IL- $1 \beta$ and/or IL- 4 , IL- 6 and TNF $\alpha$ on the activation of $\mathrm{NF} \kappa \mathrm{B}$ and on the activity and expression of MnSOD in differentiated neuroblastoma cells. A number of neurodegenerative disorders are characterised by an increase in the level of proinflammatory cytokines (Neuroinflammatory Working Group, 2000). These cytokines can modulate several intracellular signal transduction pathways in neuronal cells, e.g. via activation of $\mathrm{NF} \kappa \mathrm{B}$ or induction of COX-2 expression (Fiebich et al., 2000), which my lead to cell destruction. Neuroblastoma cell culture appeares to be a good experimental model for examining the influence of cytokine network on neuronal metabolism. SH-SY5Y cells can be morphologically differentiated into neuronal cells, whose phenotype varies depending on the inducing factors, e.g. retinoic acid, nerve growth factor, dibutyryl cyclic AMP or TPA (Yu et al., 1988).

\section{MATERIALS AND METHODS}

SH-SY5Y cells were kindly donated by Prof. A. Szczudlik (Collegim Medicum, Jagiellonian University, Kraków, Poland). IL-6 was provided by Prof. P.C. Heinrich (Germany), and IL-1 $\beta$ by Prof. Ch. Dinarello (U.S.A). The DMEM medium and fetal bovine serum (FBS) were purchased from Gibco Life Technologies
Inc. (U.S.A). [ $\alpha^{32}$ P]dCTP was from ICN Pharmaceuticals, Inc. (U.S.A.), and the MnSOD cDNA probe from the ATCC (U.S.A). Antibiotics (penicillin, streptomycin) were obtained from Polfa (Tarchomin, Poland), human IL-4 and other reagents from Sigma.

Cell culture. SH-SY5Y neuroblastoma cells were cultured at $37^{\circ} \mathrm{C}$ in $75 \mathrm{~cm}^{2}$ flasks containing DMEM supplemented with $10 \%$ FBS and antibiotics under a humidified atmosphere of $95 \%$ air and $5 \% \mathrm{CO}_{2}$. The cells were differentiated with retinoic acid (RA) $(10 \mu \mathrm{M})$ for $72 \mathrm{~h}$ (Scheibe \& Wagner, 1992). For isolation of nuclear proteins and total RNA, as well as for MnSOD activity assay, the SH-SY5Y cells were cultured in $60 \mathrm{~mm}$ Petri dishes. The medium was changed $24 \mathrm{~h}$ before addition of the following cytokines: IL- $1 \beta(10 \mathrm{ng} / \mathrm{ml})$ and/or TNF $\alpha$ (10 ng/ml), IL-4 (100 U/ml) and IL-6 $(25 \mathrm{ng} / \mathrm{ml})$. In some assays, the culture medium was supplemented with pyrrolidine dithiocarbamate (PDTC) $(100 \mu \mathrm{M}) 1 \mathrm{~h}$ prior to IL-1 addition.

Nuclear extracts were isolated after $90 \mathrm{~min}$, and total cellular RNA after $8 \mathrm{~h}$ of cytokine or PDTC treatment. The activity of MnSOD was estimated in cells cultured with the specific cytokines or PDTC for $24 \mathrm{~h}$.

Nuclear protein extraction and EMSA. Nuclear extracts were prepared by a mini-extraction procedure (Suzuki, 1994). The retinoic acid-differentiated neuroblastoma cells were cultured for 90 min with IL-1 (10 $\mathrm{ng} / \mathrm{ml}$ ), or a mixture of IL-1 and TNF (10 $\mathrm{ng} / \mathrm{ml})$, or IL-4 (100 U/ml), or IL-6 (25 ng/ml); they were then washed with cold phosphatebuffered saline (PBS), collected and centrifuged for $5 \mathrm{~min}$ at $400 \times \mathrm{g}$. The cells, previously resuspended in a buffer $(10 \mathrm{mM} \mathrm{NaCl}, 3$ $\mathrm{mM} \mathrm{MgCl} 2,10 \mathrm{mM}$ Tris, $\mathrm{pH} 7.5$, and $0.2 \mathrm{mM}$ phenylmethylsulfonyl fluoride, PMSF), were incubated on ice for $15 \mathrm{~min}$. Nonidet NP-40 was added, and samples were centrifuged for $60 \mathrm{~s}$ at 14000 r.p.m. Pelleted nuclei were resuspended in a buffer (10 mM Hepes, 0.35 M $\mathrm{NaCl}, 5 \mathrm{mM}$ EDTA, $1 \mathrm{mM}$ dithiothreitol (DTT) and $0.2 \mathrm{mM} \mathrm{PMSF}$ ) and centrifuged for $5 \mathrm{~min}$ 
at 14000 r.p.m. After centrifugation at $4^{\circ} \mathrm{C}$, the supernatant proteins were measured by the BCA method. The remainder of the supernatant was frozen in $10 \%$ glycerol.

For NF $\kappa \mathrm{B}$ activity assay (a DNA electrophoretic mobility shift assay), nuclear protein extracts $(10 \mu \mathrm{g})$ were incubated for $30 \mathrm{~min}$ at a room temperature in $25 \mu \mathrm{l}$ of the binding buffer $(0.5 \%$ Triton X-100, 2.5\% glycerol, 10 $\mathrm{mM}$ Hepes, $4 \mathrm{mM}$ DTT) containing $0.5 \mathrm{ng}$ of ${ }^{32}$ P-end-labelled NF $\kappa$ B-binding oligonucleotide (about $10^{5}$ c.p.m.) and $1 \mu \mathrm{g}$ of poly(dI-dC) (which was used as competitor). DNA-protein complexes were separated in a $5 \%$ polyacrylamide gel for $1.5 \mathrm{~h}$ at $140 \mathrm{~V}$. The dried gels were analysed by authoradiography. The relative intensity of the bands was evaluated densitometrically using the computer imaging system Fluor S MultiImager (BioRad).

RNA extraction and Northern blots. The Chomczynski's extraction method (Chomczynski \& Sacchi, 1987) and isopropanol precipitation were used for total RNA isolation from the neuroblastoma cells treated for $8 \mathrm{~h}$ with the analysed cytokines or PDTC. RNA samples $(10 \mu \mathrm{g})$ were separated by electrophoresis in a $1 \%$ agarose gel under denaturing conditions. After electrophoresis, RNA was transferred to Hybond-N membranes (Amer- sham) according to the manufacturer's instructions. The filters were prehybridized at $68^{\circ} \mathrm{C}$ for $3 \mathrm{~h}$ in $10 \%$ dextrane sulphate and $1 \%$ SDS, and were hybridized in the same solution overnight at $65^{\circ} \mathrm{C}$ with a ${ }^{32} \mathrm{P}$-labelled human MnSOD cDNA probe and subjected to autoradiography. The relative intensity of the bands was evaluated densitometrically using the computer imaging system Fluor S MultiImager (BioRad).

SOD activity evaluation. The cells were treated with cytokines or PDTC for $24 \mathrm{~h}$, washed twice with cold PBS, harvested in 0.2 $\mathrm{ml}$ of PBS, frozen and thawed four times in liquid nitrogen, each time under stirring. The mixture was centrifuged for $2 \mathrm{~min}$ (14000 r.p.m., $4^{\circ} \mathrm{C}$ ) and the supernatant was used for SOD activity measurement. A BCA kit was used for cellular protein estimation. Protein samples $(10 \mu \mathrm{g})$ were separated in a $15 \%$ polyacrylamide gel, $180 \mathrm{~V}$, for $80 \mathrm{~min}$ in a Tris/glycine buffer. After electrophoresis, the gel was immersed in a staining buffer containing riboflavin $(50 \mathrm{mM}$ phosphate buffer, $\mathrm{pH}$ 7.8, $10 \mathrm{mM}$ EDTA, $245 \mu \mathrm{M}$ nitro blue tetrazolium, NBT, $28 \mathrm{mM}$ TEMED, $30 \mu \mathrm{M}$ riboflavin), stirred in the dark and then exposed to light until white bands appeared on a blue background.
A.

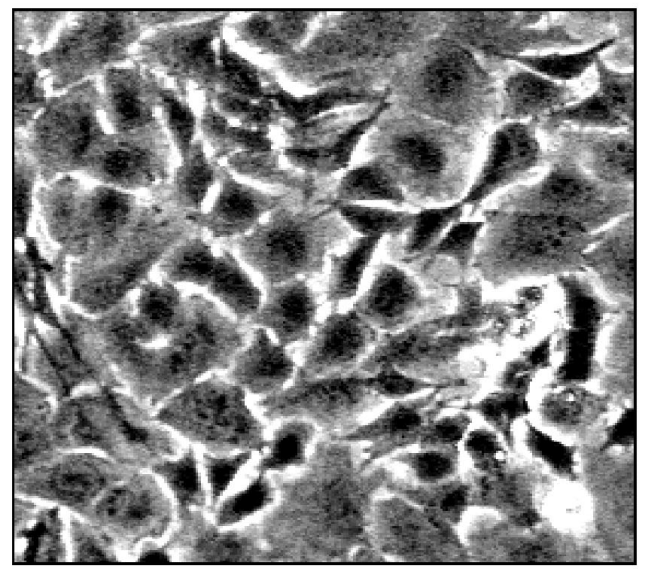

B.

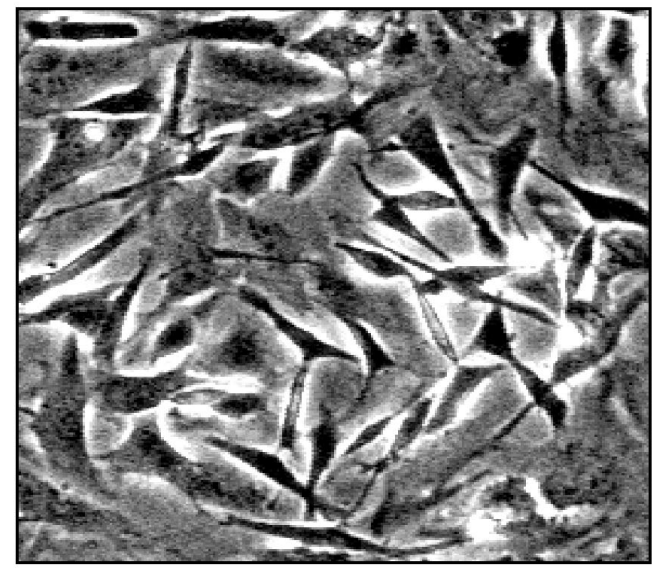

Figure 1. Morphological changes in SH-SY5Y human neuroblastoma cells after treatment with $10 \mu$ M retinoic acid for $72 \mathrm{~h}$.

A, control; B, differentiated cells. 


\section{RESULTS}

As shown in Fig. 1 exposure of SH-SY5Y cells to $10 \mu \mathrm{M}$ RA for $72 \mathrm{~h}$ led to their differentiation. We used a $\mathrm{NF} \kappa \mathrm{B}$ consensus oligonucleotide for EMSA analysis to determine whether IL-4, IL-6 or TNF cooperate with IL-1 in $\mathrm{NF} \kappa \mathrm{B}$ activation. Figure 2 demonstrates that IL-1 is the main inducer of this transcrip-

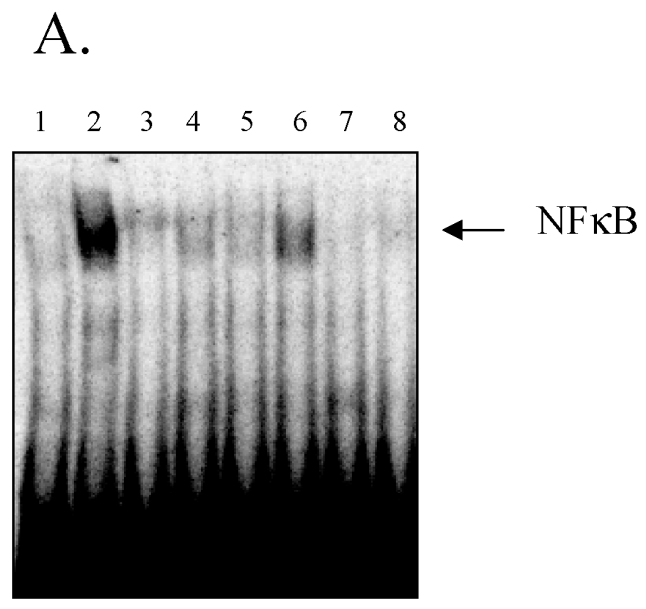

\section{B.}

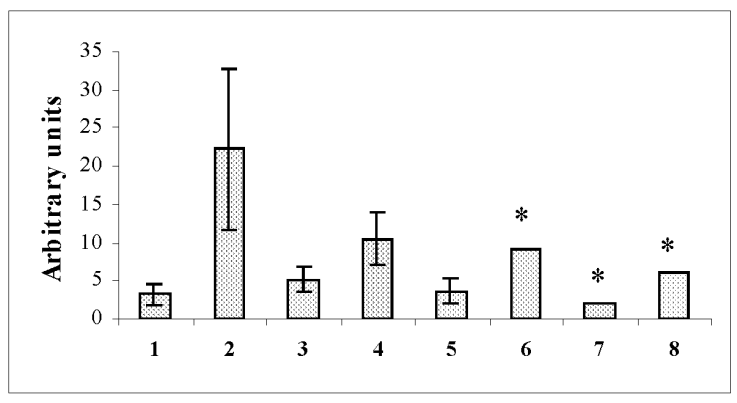

greatly enhanced by IL-1, but the modifying effect exerted by IL-4, IL-6 and TNF was less potent (Fig. 4). It was found previously that retinoic acid affected MnSOD protein stability, but not expression (Ahlemeyer et al., 2001), hence some interference of the RA-produced effects with those of IL-4, IL-6 or TNF should be considered. Neither of the cytokines examined was capable of affecting CuZnSOD activ-

Figure 2. Effect of treatment (for $90 \mathrm{~min}$ ) with IL-1 (10 $\mathrm{ng} / \mathrm{ml})$ and/or IL-4 (100 $\mathrm{U} / \mathrm{ml}$ ), IL-6 (25 ng/ml), TNF (10 ng/ml) on $\mathrm{NF} \kappa \mathrm{B}$ activation.

The cell extract was incubated with a radioactively labelled oligonucleotide containing a $\mathrm{NF} \kappa \mathrm{B}$ consensus binding sequence. The reaction mixture was separated on a native polyacrylamide gel. Lane: 1, control; 2 , IL-1; 3 , IL-4; 4, IL-1+IL-4; 5, IL-6; 6, IL-1+IL-6; 7, TNF; 8, IL-1+TNF. A. Representative gel; B. Scanning data presented in arbitrary units; mean of three experiments. The bars represent \pm S.D. mean of two results.

tion factor. In contrast, TNF $\alpha$ had no effect on $\mathrm{NF} \kappa \mathrm{B}$ binding activity, and even decreased the IL-1-elicited $\mathrm{NF} \kappa \mathrm{B}$ activation. However, these results should be further analysed. As expected IL- 4 and IL- 6 decreased the NF $\kappa \mathrm{B}$ activation induced by IL-1.

The regulation of MnSOD expression by the tested cytokines showed a response pattern similar to that observed for $\mathrm{NF} \kappa \mathrm{B}$ activation (Fig. 3). IL-1 distinctly up-regulated MnSOD expression in the differentiated neuroblastoma cells, whereas IL-4, IL-6 and TNF partly reversed that effect. The enzyme activity was ity (Fig. 4), but PDTC, an inhibitor of NF $\kappa \mathrm{B}$ activation (Bowie et al., 1997), diminished the activity of this enzyme (Fig. 5B). PDTC inhibited both the IL-1-induced NF $\kappa$ B binding (Fig. 6) and the IL-1-elicited MnSOD expression and activity (Fig. 5A, B).

\section{DISCUSSION}

In the present report we describe the effects of proinflammatory (IL-1, TNF) and so-called antiinflammatory cytokines (IL-4, IL-6) on 
the oxidant status of RA-differentiated (as demonstrated by morphological criteria) neuroblastoma cells, as measured by activation of the oxidative stress-responsive $\mathrm{NF} \kappa \mathrm{B}$, as well as by expression and activity of the main inducible antioxidant enzyme MnSOD.

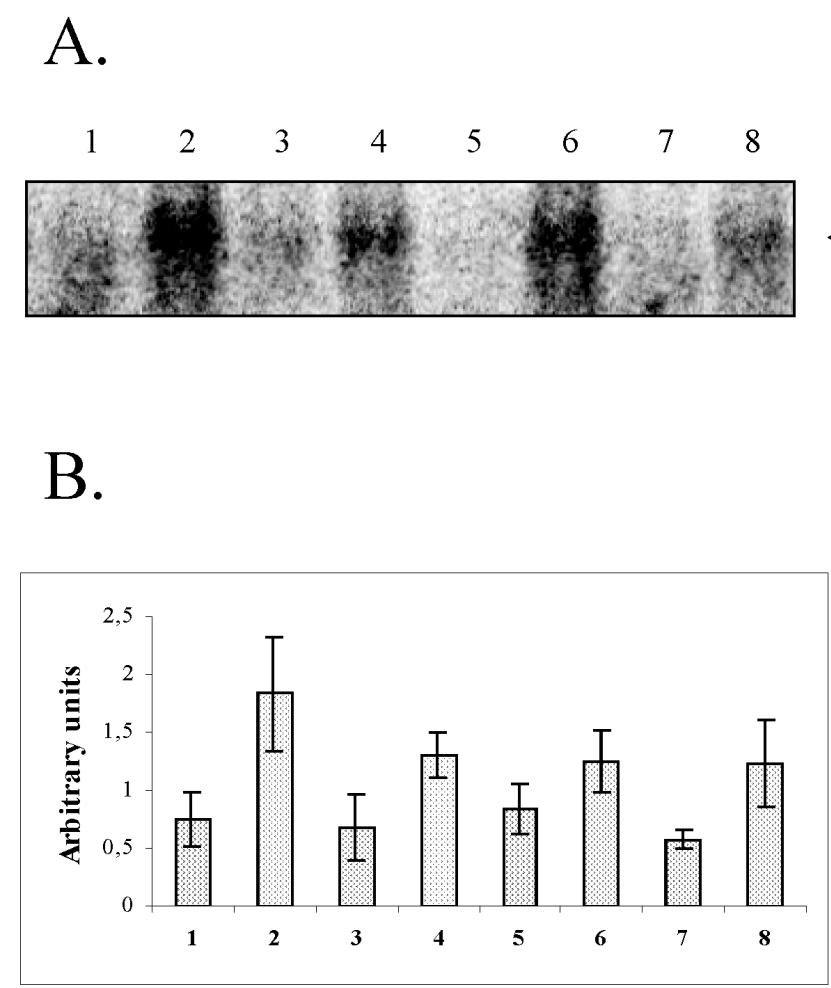

neuroblastoma SK-N-SH cells and some other tumour cells. The nuclear factor $\kappa \mathrm{B}$ is regarded as an antiapoptotic factor in neuroblastoma cells (Yabe et al., 2001; Bian et al., 2002). However, prolonged activation of $\mathrm{NF} \kappa \mathrm{B}$ may be dangerous to the cell. It seems

\section{$\longleftarrow \mathrm{MnSOD}$}

Figure 3. Effect of IL-1 (10 $\mathrm{ng} / \mathrm{ml})$ and/or IL-4 (100 U/ml), IL-6 (25 ng/ml), TNF (10 ng/ml) on MnSOD mRNA expression.

Total RNA was analysed by Northern blot hybridization. 1, control; 2 , IL-1; 3, IL-4; 4, IL-1+IL-4; 5, IL-6; 6 , IL-1+IL-6; 7, TNF; 8, IL-1+TNF.

A. Representative blot; B. Scanning data presented in arbitrary units after normalization against 18 sRNA; mean of three experiments; the bars represent \pm S.D.

Several studies have reported the induction of $\mathrm{NF} \kappa \mathrm{B}$ binding activity by IL-1 (Fig. 2), whereas the effectiveness of TNF seems to be cell-type-specific. As is shown in Fig. 2, TNF is unable to activate $\mathrm{NF} \kappa \mathrm{B}$ in the RA-differentiated neuronal SH-SY5Y cells. A similar observation was made by Wong (1995) with

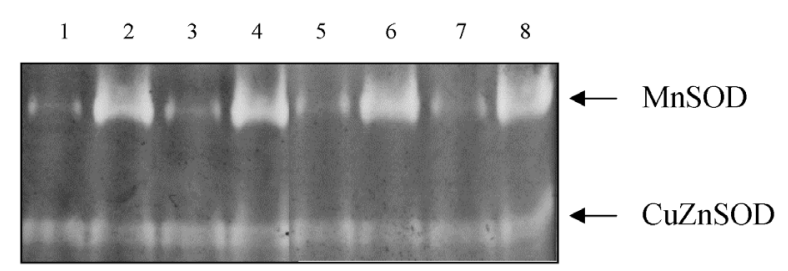

Figure 4. Influence of IL-1 (10 ng/ml) and/or IL-4 (100 U/ml), IL-6 (25 ng/ml), TNF (10 ng/ml) on the activity of MnSOD and CuZnSOD in cells cultured for $24 \mathrm{~h}$ with the indicated cytokines.

1, control; 2, IL-1; 3, IL-4; 4, IL-1+IL-4; 5, IL-6; 6, IL-1+IL-6; 7, TNF; 8, IL 1+TNF. that IL-4 and IL-6 can abrogate the IL-1-elicited effect on nuclear factor $\kappa$ B activation. Cellular responses to cytokines depend on receptors, signalling molecules and the stage of cell differentiation. The cytokine-activated transcription factors $\mathrm{NF} \kappa \mathrm{B}, \mathrm{C} / \mathrm{EBP}$ and STATs regulate individually or cooperatively the expression of target genes. Gene expression is determined by interactions between transcription factors, the promoter context of the target gene, and the presence of co-activator complexes. A cross-talk between the $\mathrm{C} / \mathrm{EBP}$, STAT and $\mathrm{NF} \kappa \mathrm{B}$ signal transduction pathways has been postulated (Luo \& Yu-Lee, 2000; Kiningham et al., 2001; Cisowski et al., 2002). It is possible that the STAT pathway, which is activated by IL-4 or IL-6, may inhibit the $\mathrm{NF} \kappa \mathrm{B}$ binding induced by IL-1 in neuroblastoma cells (experiments in progress). 


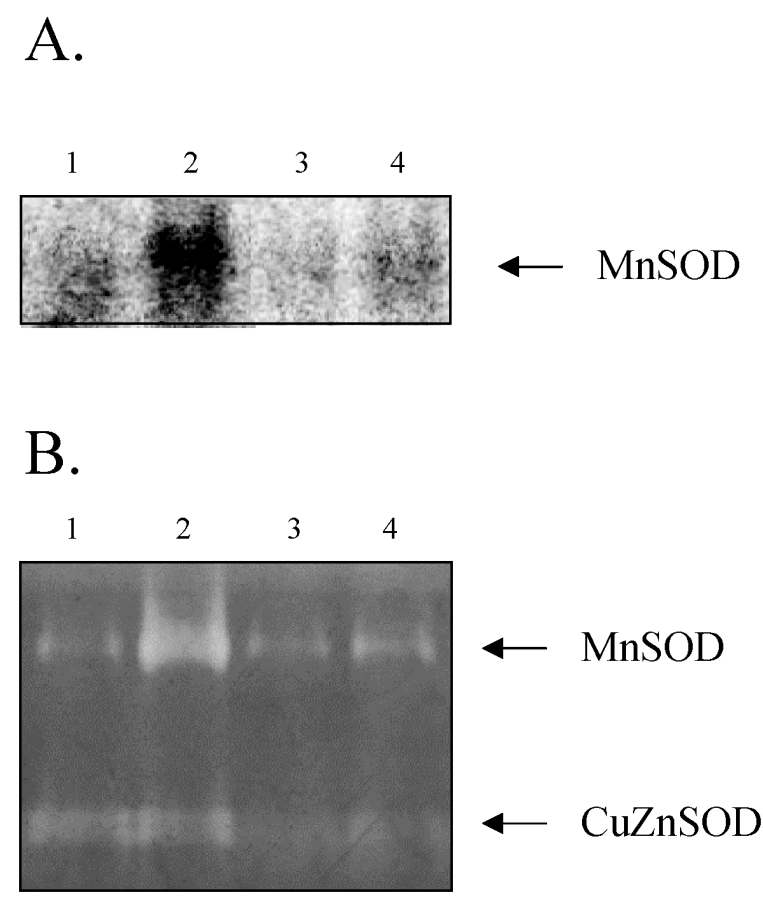

Figure 5. Effect of PDTC $(100 \mu \mathrm{M})$ on MnSOD expression (A) and MnSOD and CuZnSOD activity (B).

Lane 1, control; 2, IL-1; 3, PDTC; 4, IL-1+ PDTC.

The brain is particularly susceptible to oxygen free radicals which are implicated in the pathology of several neurological disorders (Jenner, 2003; Pong, 2003; Klein \& Ackerman, 2003). The antioxidant enzyme system of the brain may play an important role in the protection against oxidative stress. The induction of MnSOD, an enzyme converting superoxide anion to hydrogen peroxide, by IL- 1 can protect cells against the damaging effects of reactive oxygen species. MnSOD overexpression, in human neuronal cells expressing mutant CuZnSOD, attenuated neuronal death (Flanagan et al., 2002). CuZnSOD - overexpressing astrocytoma cells also show increased resistance to oxidative injury (Chen $e t$ al., 2001). IL-4 and IL-6 seem to be capable of normalizing the IL-1-produced effects. Depending on the activation of astrocytes, glial and neuronal cells in the CNS, different subsets of cytokines can be generated; they can modulate neuronal cell metabolism resulting in cell

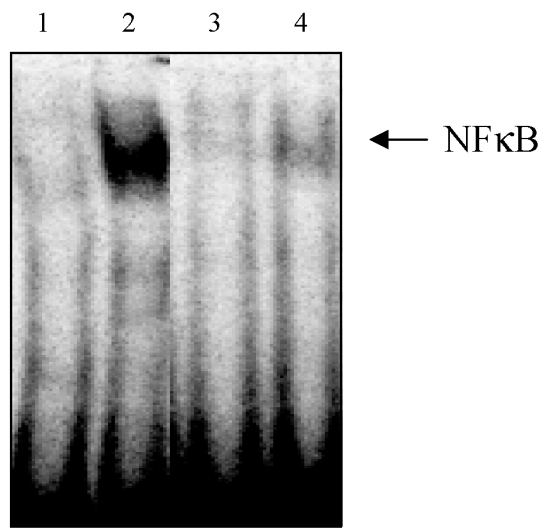

Figure 6. Inhibitory effect of PDTC $(100 \mu \mathrm{M})$ on $\mathrm{NF} \kappa \mathrm{B}$ activation in neuroblastoma cells treated with IL-1 (10 $\mathrm{ng} / \mathrm{ml}$ ) for $90 \mathrm{~min}$.

Lane 1, control; 2, IL-1; 3, PDTC; 4, IL-1+PDTC.

protection or damage (Klegeris \& McGeere, 2001).

Pyrollidine dithiocarbamate (PDTC), a metal chelator and antioxidant, inhibits $\mathrm{NF} \kappa \mathrm{B}$ due to its dithiocarbamate moiety (Bowie et al., 1997). Dithiocarbamates have been used clinically for treating various pathogenic fungi and bacteria, as well as in agricultural insecticides, herbicides and fungicides (Nobel et al., 1995). PDTC inhibits CuZnSOD activity (Erlejman \& Oteiza, 2002; and Fig. 5B) and as was shown in our experiments - decreases the IL-1 induced MnSOD activation. On the basis of the above observations we postulate that the transcription factor $\kappa \mathrm{B}$ is crucial for MnSOD up-regulation in differentiated neuroblastoma cells.

\section{R E F E R E N C E S}

Antras-Ferry J, Maheo K, Morel F, Guillouzo A, Cillard P, Cillard J. (1997) Dexamethasone differently modulates TNF $\alpha$ and IL- $1 \beta$-induced transcription of the hepatic Mn-superoxide dismutase gene. FEBS Lett.; 403: $100-1$.

Ahlemeyer B, Bauerbach E, Plath M, Steuber M, Heers C, Tegtmeier, Kriegstein J. (2001) Retinoic acid reduces apoptosis and oxida- 
tive stress by preservation of SOD protein level. Free Radic Biol Med.; 30: 1067-77.

Bian X, Opipari AW, Ratanaproeksa AB, Boitano AE, Lucas PVP. (2002) Constitutively active $\mathrm{NF} \kappa \mathrm{B}$ is required for the survival of neuroblastoma. J Biol Chem.; 277: 42144-50.

Bowie AG, O’Neill LA. (2000) Oxidative stress and nuclear factor-kappa B. Biochem Pharmacol.; 59: 13-23.

Bowie AG, Moynagh PN, O’Neill LAJ. (1997) Lipid peroxidation is involved in the activation of $\mathrm{NF} \kappa \mathrm{B}$ by tumor necrosis factor but not IL-1 in the human endothelial cell line ECV304. J Biol Chem.; 272: 25941-50.

Chen Y, Chan PH, Swanson RA. (2001) Astrocytes overexpressing $\mathrm{Cu}, \mathrm{Zn}$ superoxide dismutase have increased resistance to oxidative injury. Glia.; 33: 343-7.

Chomczynski P, Sacchi N. (1987) Single-step method of RNA isolation by acid guanidinium thiocyanate-phenol-chloroform extraction. Anal. Biochem.; 162: 156-7.

Cisowski J, Zarębski A, Koj A. (2002) IL-1 mediated inhibition of IL-6-induced STAT3 activation is modulated by IL-4, MAP kinase inhibitor and redox state of HepG2 cells. Folia Histochem Cytobiol.; 40: 341-5.

Erlejman AG, Oteiza PI. (2002) The oxidant defense system in human neuroblastoma IMR predifferentiation and postdifferentiation to neuronal phenotype. Neurochem Res.; 27: 1499-506.

Fiebich BL, Mueksch B, Boehringer M, Hull M. (2000) Interleukin- $1 \beta$ induces cyclooxygenase-2 and prostaglandin E2 synthesis in human neuroblastoma cells: Involvement of p38 mitogen-activated protein kinase and nuclear factor- $\kappa$ B. $J$ Neurochem.; 75: 2020-8.

Flanagan SW, Anderson RD, Ross MA, Oberley LW. (2002) Overexpression of manganese superoxide dismutase attenuates neuronal death in human cells expressing mutant (G37R) $\mathrm{Cu} / \mathrm{Zn}$-superoxide dismutase. $J$ Neurochem.; 81: 170-7.
Israel A. (2000) The IKK complex: an integrator of all signals that activate $\mathrm{NF} \kappa \mathrm{B}$ ? Trends Cell Biol.; 10: 129-33.

Jenner P. (2003) Oxidative stress in Parkinson's disease. Ann Neurol.; 53 Suppl 3: 3S26-36.

Karin M, Lin A. (2002) NF $\kappa$ B at the crossroads of life and death. Nature Immunol.; 3: 221-7.

Kiningham KK, Xu Y, Daosukho C, Popova B, St Clair DK. (2001) Nuclear factor $\kappa$ B-dependent mechanisms coordinate the synergistic effect of PMA and cytokines on the induction of superoxide dismutase 2 . Biochem J.; 353: 147-56.

Klegeris A, McGeer PL. (2001) Inflammatory cytokine levels are influenced by interactions between THP-1 monocytic, U-373 MG astrocytic, and SH-SY5Y neuronal cell lines of human origin. Neurosci Let.; 313: 41-4.

Klein JA, Ackerman SL. (2003) Oxidative stress, cell cycle, and neurodegeneration. J Clin Invest.; 111: 785-93.

Luo G, Yu-Lee L. (2000) Stat5b inhibits NF $\kappa$ B mediated signaling. Mol Endocrinol.; 14: 114-21.

Neuroinflammation Working Group. (2000) Inflammation and Alzheimer's disease. Neurobiol Aging.; 21: 383-421.

Nobel CSI, Kimland M, Lind B, Orrenius S, Slater AFG. (1995) Dithiocarbamates induce apoptosis in thymocytes by raising the intracellular level of redox-active copper. $J$ Biol Chem.; 270: 26202-8.

Pahl HL. (1999) Activators and target genes of Rel/NFB transcription factors. Oncogene.; 18: $6853-66$.

Pong K. (2003) Oxidative stress in neurodegenerative diseases: therapeutic implications for superoxide dismutase mimetics. Expert Opin Biol Ther:; 3: 127-39.

Rogers RJ, Monnier JM, Nick HS. (2001) Tumor necrosis factor- $\alpha$ selectively induces $M n S O D$ expression via mitochondria-to-nucleus signaling, whereas interleukin- $1 \beta$ utilizes an alternative pathway. $J$ Biol Chem.; 276: 20419-27. 
Scheibe RJ, Wagner JA. (1992) Retinoic acid regulates both expression of the nerve growth factor receptor and sensitivity to nerve growth factor. J Biol Chem.; 267: 17611-6.

Suzuki YJ, Mizuno M, Packer L. (1994) Signal transduction for nuclear factor $\kappa \mathrm{B}$ activation. Proposed location of antioxidant-inhibitable step. J Immunol.; 153: 5008-15.

Wong GHW. (1995) Protective roles of cytokines against radiation induction of mitochondrial MnSOD. Biochim Biophys Acta.; 1271: 205-9.

Xu Y, Kiningham KK, Devalaraja MN, Yeh CC, Majima H, Kasarskis EJ, St Clair DK. (1999)
An intronic NF-kappa B element is essential for induction of the human manganese superoxide dismutase gene by tumor necrosis factor-alpha and interleukin-1 beta. $D N A$ Cell Biol.; 18: 709-22.

Yabe T, Wilson D, Schwartz JP. (2001) NF $\kappa$ B activation is required for the neuroprotective effect of pigment epithelium-derived factor (PEDF) on cerebellar granule neurons. $J$ Biol Chem.; 276: 43313-19.

Yu VC, Hochhaus G, Chang FH, Richards ML, Bourne HR, Sadee W. (1988) Differentiation of human neuroblastoma cells: marked potentiation of prostaglandin E-stimulated accumulation of cyclic AMP by retinoic acid. J Neurochem.; 51: 1892-9. 